\title{
Retinometra albeolae n.sp. (Cestoda: Hymenolepididae) from the bufflehead duck, Bucephala albeola $\mathrm{L}$.
}

\author{
Michael J. EWART \\ Department of Biology, Concordia University, 1455 de Maisonneuve Boulevard West, Montréal, Que., Canada H3G 1 M8 \\ AND \\ J. Daniel Mclaughlin \\ Department of Biology, Concordia University, 1455 de Maisonneuve Boulevard West, Montréal, Que., Canada H3G 1 M8 \\ and Delta Waterfowl and Wetlands Research Station, R.R. I Portage la Prairie, Man., Canada RIN 3A1
}

Received July 6, 1989

\begin{abstract}
Ewart, M. J., and McLaughlin, J. D. 1990. Retinometra albeolae n.sp. (Cestoda: Hymenolepididae) from the bufflehead duck, Bucephala albeola L. Can. J. Zool. 68: 1086-1089.

Retinometra albeolae $\mathrm{n} . \mathrm{sp}$. is described from bufflehead ducks (Bucephala albeola L.) from Manitoba, Canada. It is armed with eight skrjabinoid rostellar hooks $69-75 \mu \mathrm{m}$ long, and has a cirrus sac $240-480 \mu \mathrm{m}$ long that extends to approximately the midline of mature proglottids, a trilobed ovary, and a lobed vitelline gland. Staphylepis indica and Staphylepis meggitti, currently included in the genus Retinometra, are returned to Staphylepis on the basis of proglottid morphology and the apparent lack of a cirrus stylet in both species.
\end{abstract}

Ewart, M. J., et Mclaughlin, J. D. 1990. Retinometra albeolae n.sp. (Cestoda: Hymenolepididae) from the bufflehead duck, Bucephala albeola L. Can. J. Zool. 68 : 1086-1089.

On trouvera ici la description de Retinometra albeolae n.sp., trouvé chez des Petits Garrots (Bucephala albeola L.) au Manitoba, Canada. Le parasite est armé de huit crochets rostellaires skrjabinoïdes de 69-75 $\mu \mathrm{m}$ de longueur et porte une poche du cirre de 240-480 $\mu \mathrm{m}$ de longueur, qui s'étend environ jusqu'à la ligne médiane des proglottis à maturité, ainsi qu'un ovaire trilobé et une glande vitelline lobée. Staphylepis indica et Staphylepis meggitti, actuellement inclus dans le genre Retinometra, sont retransférés au genre Staphylepis à cause de la morphologie de leurs proglottis et de l'absence apparente d'un stylet sur le cirre des deux espèces.

[Traduit par la revue]

\section{Introduction}

During the study of helminths from bufflehead ducks (Bucephala albeola L.) collected on the Delta Marsh, Delta, Manitoba, Canada, specimens belonging to the hymenolepidid genus Retinometra Spasskii, 1955, possessing rostellar hooks 69-75 $\mu \mathrm{m}$ long, were encountered. The morphology of these specimens differs from that of other species of Retinometra armed with rostellar hooks of similar length. Nor do they resemble any of the avian hymenolepidids included in the genus Hymenolepis s.l. by Yamaguti (1959) and Schmidt (1986). We consider these specimens to represent a new species, described herein.

\section{Materials and methods}

Twenty-four buffleheads were collected during spring and fall migration at Delta, Manitoba, Canada. They were shot with a 12-gauge shotgun in May and June, and obtained from duck hunters in October. A single duck, which became flightless on a small pond at Delta, was shot in early September.

The gastrointestinal tract was removed and opened under water, and the contents were searched for helminths, using a stereomicroscope. Cestodes were fixed in 5\% formalin $(24 \mathrm{~h})$, then stored in $70 \%$ ethanol. Specimens were stained in acetocarmine, dehydrated, cleared in xylene, and mounted in Permount. Measurements and drawings were made on a Wild M-20 microscope with an attached drawing tube. All measurements are given in micrometres unless stated otherwise.

\section{Results}

Thirteen buffleheads ( 5 in spring, the September specimen, and 7 in fall) were found to be infected with the new species. Migrant individuals harboured 1-8 $(\bar{x}=3.4)$ and 1-9 specimens $(\bar{x}=4.6)$ in spring and fall, respectively. The local duck harboured 88 individuals. Details of the other helminths encountered will be presented elsewhere.

\section{Retinometra albeolae $\mathrm{n} . \mathrm{sp}$.}

With characteristics of the genus. Description based on 15 specimens. Four of these were complete; two were gravid. Values in parentheses following a range represent the mean.

Medium-sized cestodes up to $55 \mathrm{~mm}$ long by up to $1.9 \mathrm{~mm}$ wide when gravid. Proglottids craspedote, a condition exaggerated in contracted specimens. Proglottids all wider than long. Genital apertures situated on anterior half of proglottid margin; genital atrium deep.

Scolices (Fig. 1) 156-201 (170) long (measured from tip of rostellar sheath to base of rostellar sac) by 192-230 (208) across suckers. Suckers oval, weakly muscled, 84-134 (113) long by 84-115 (96) wide. Rostellum (Fig. 1) muscular, 168-204 (188) long. Basal portion narrow 12-14 (13) wide, middle region 43-60 (49) wide, and apex 43-48 (46) wide. Middle region and apex separated by a conspicuous constriction. Rostellum armed with 8 skrjabinoid hooks 69-75 (72) long (Fig. 2).

Measurements of internal structures were begun from those proglottids in which sperm could first be discerned in the external seminal vesicle. Measurements of all structures were made in every third proglottid from this point posteriorly to the end of the strobila. Testes 100-288 (190) long by 106-288 (173) wide. Middle testis extends slightly more posterior than the other two (Figs. 3 and 4). Testes spherical to subspherical in young proglottids; subspherical in older ones. Shape of middle testis more variable than that of other two. Poral and antiporal testes may overlap excretory vessels in mature proglottids but do not extend beyond them. Testis surface generally smooth; however, occasional specimens with lobed testes were found. Cirrus sac 240-480 (364) long by 48-106 (74) wide. The majority, however, fell within a narrower range $(288-432 \times$ $62-82$ ) and only $12.5 \%$ of the 160 measured lay outside this range. The larger cirrus sacs occurred primarily in gravid 

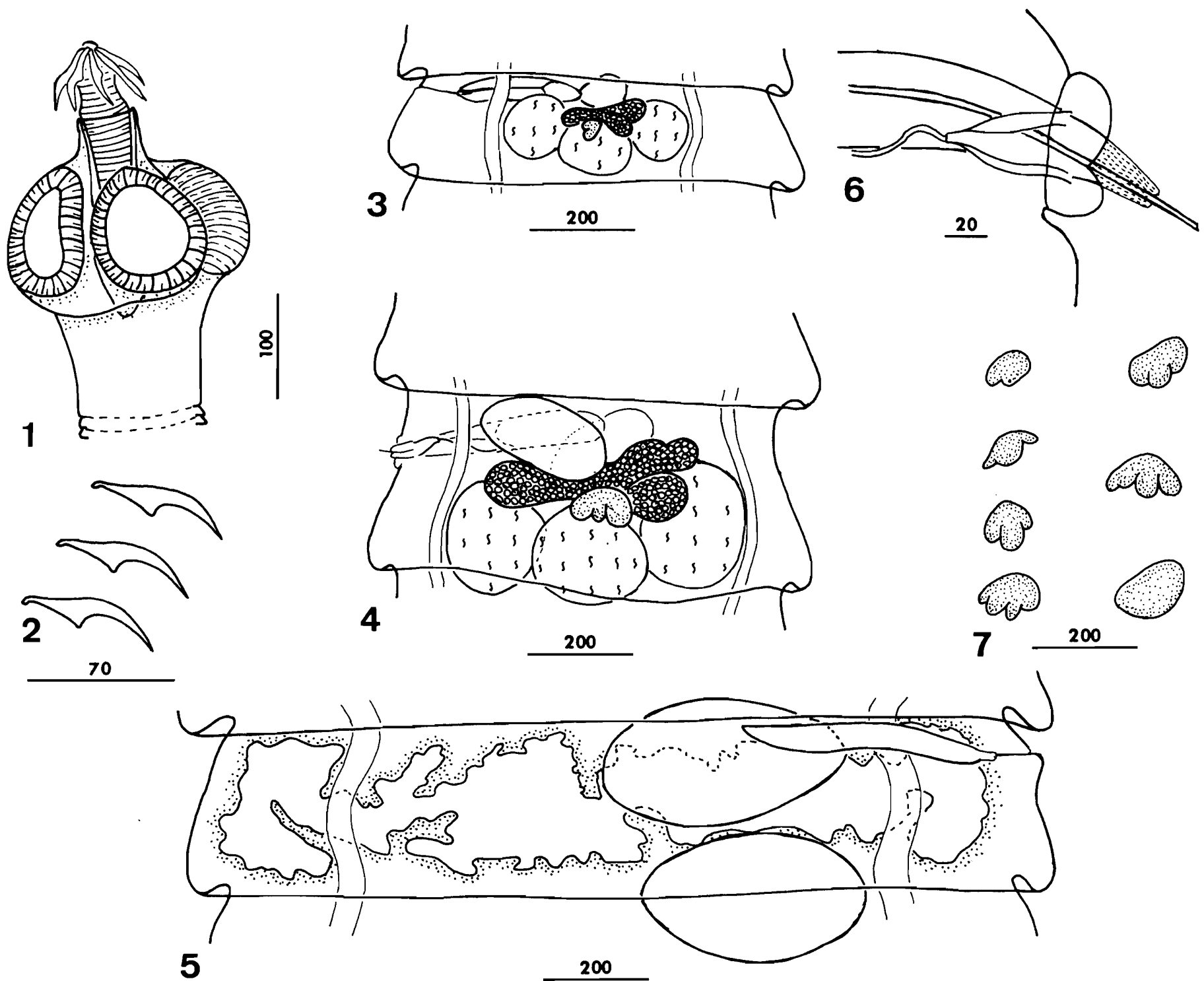

FIGS. 1-7. Retinometra albeolae n.sp. Fig. 1. Scolex. Fig. 2. Rostellar hooks. Fig. 3. Young proglottid; dorsal excretory canals omitted. Fig. 4. Mature proglottid; dorsal excretory canals omitted. Fig. 5. Gravid proglottid showing uterus, seminal receptacle and cirrus sac; dorsal excretory canals omitted. Fig. 6. Cirrus and vagina. Fig. 7. Variation in shape of the vitelline gland within a single strobila. All scale bars are in micrometres.

proglottids. Cirrus sac extends to area of midline in young (Fig. 3) and mature (Fig. 4) proglottids, but terminates well short of it in gravid proglottids (Fig. 5). Internal seminal vesicle occupies antiporal $2 / 3$ of cirrus sac when full. External seminal vesicle oval, 120-288 (189) $\times 52-120(98)$ wide, and situated dorsal to antiporal tip of cirrus sac in the middle $1 / 3$ of the proglottid (Figs. 3 and 4). Cirrus (Fig. 6) short, subcylindrical, 36-60 (50) long $\times 21-29(26)$ at the base, 9-16(11) at the tip, and covered with a uniform layer of minute spines. Everted cirrus surrounded by a collarlike fold of tissue around its base. Stylet up to 168 long present but not observed fully everted.

Ovary trilobed, median, ventral, and either anterior to middle testis or overlapping its anterior edge (Figs. 3 and 4). Bi- and 4-lobed ovaries occasionally seen. Lobes of ovary smooth in young and mature proglottids, becoming lobulated with age, usually along posterior margin. Poral lobe eventually becomes flattened by expanding seminal receptacle. Ovary attains a maximum width of about 780 before disappearing. At this point it extends to, but not beyond,the excretory vessels. It disappears abruptly some $15-24$ proglottids posterior to the first proglottid where the developing uterus can be seen extending beyond the excretory vessels. Vitelline gland 48-182 (121) $\times$ 48-177 (98), median, postovarian (Figs. 3 and 4). Shape variable, usually with 3 or 4 lobes directed posteriorly, but oval vitelline glands with smooth surfaces often found (Fig. 7). Vagina with funnel-shaped copulatory portion 48-84 (61) long (Fig. 6). Seminal receptacle oval $154-480(312) \times 82-264(157)$ in poral half of proglottid, ventral to cirrus sac and initially anterior to ovary. The majority of seminal receptacles $336 \times 168$ or larger occurred in proglottids exhibiting uterine development (Fig. 5). Uterus a transverse sac with outpocketings which subsequently break down (Fig. 5). Oncospheres $(n=10)$ measured in utero oval, 26-34 (29) $\times 12-17$ (16), with hooks 11 long.

TYPE HOST: Bucephala albeola L. LOCATION IN HOST: Mid to posterior small intestine. TYPE LOCALITY: Delta Marsh, Delta, Manitoba, Canada. 
HOLOTYPE: Canadian National Museum of Natural Sciences NMCP1989-0242.

PARATYPES: Canadian National Museum of Natural Sciences NMCP1989-0243, 44, and 45 (with eggs).

\section{Discussion}

As presently constituted, the genus Retinometra includes six species, each with 8 rostellar hooks which either overlap in length or lie within $10 \mu \mathrm{m}$ of the upper or lower range of those present on $R$. albeolae (Schmidt 1986). These include $R$. bulbocirrosus (Pfeiffer, 1960) $(68 \mu \mathrm{m}), R$. cyrtoides (Mayhew, 1925) (67-70 $\mu \mathrm{m})$, R. fista (Meggitt, 1933) (57-67 $\mu \mathrm{m})$, $R$. guberiana Czaplinski, $1965(71-75 \mu \mathrm{m})$, and $R$. oxyurae Maksimova, $1966(68 \mu \mathrm{m})$ from avian hosts, and $R$. ondatrae (Rider and Macy, 1947) (8-10 hooks, 67-73 $\mu \mathrm{m}$ ) from muskrats.

Retinometra bulbocirrosus from Cygnus melanocoryphus has a large bulbous structure (= cirrus?) associated with the genital atrium (Pfeiffer 1960) and can readily be distinguished from $R$. albeolae on this basis.

Retinometra cyrtoides is a poorly described species originally reported from Oxyura jamaicensis by Mayhew (1925), and more recently from Aythya affinis in Alberta (Bush and Holmes 1986). It is a smaller cestode than $R$. albeolae $(3-10 \mathrm{~mm})$, has a short rostellum, and has a characteristic bend in the posterior region of the strobila. Details of proglottid morphology also differ. Mayhew (1925, pp. 61 and 62) states that "in the young proglottids the testes were invariably arranged two posteriorly, one on each side of the ovary and the other anterior and lateral to the antiporal testes." These features are sufficient to distinguish it from $R$. albeolae.

Retinometra fista, described from Nettapus coromandelianus, has 8 rostellar hooks similar in shape to those of $R$. albeolae; however, they are slightly shorter and possess a more prominent guard, and the handle is longer than the blade. Cirrus sacs in mature proglottids range from 390 to $450 \mu \mathrm{m}$, reach $660 \mu \mathrm{m}$ in gravid proglottids, and may extend to the antiporal excretory vessels (Meggitt 1933). The rest of the description is sketchy, but the differences noted in the hooks and cirrus sacs are sufficient to separate the two species.

Retinometra guberiana, described from Cygnus olor in Poland, is a small cestode $(2.8-4.7 \mathrm{~mm})$, and can be further distinguished from $R$. albeolae on the basis of its smaller testes $(63-80 \times 40-78 \mu \mathrm{m})$, smaller, transversely oval vitelline gland $(38-50 \times 18-30 \mu \mathrm{m})$, smaller seminal receptacle $(150 \times 70$ $\mu \mathrm{m}$ in uterine proglottids), and differently shaped cirrus and copulatory portion of the vagina (Czaplinski 1965).

Retinometra oxyurae, described from Oxyura leucocephala, is also a small cestode (3-8 mm) (Maksimova 1966). There is extensive overlap in the size of many of the internal structures and also in the shape of the cirrus and copulatory portion of the vagina. In addition to its smaller size, $R$. oxyurae differs from $R$. albeolae in the following details: the cirrus sac in $R$. oxyurae extends well beyond the antiporal excretory vessel in mature proglottids, rather than to the midline; the ovary is bilobed rather than trilobed and the vitelline gland is smooth and subspherical rather than lobed.

Retinometra ondatrae resembles $R$. albeolae in general size, in the length and shape of the rostellar hooks, and in the presence of a cirrus sac that extends to the middle of the proglottid. The two species can be separated readily by the smaller sizes of the cirrus sac, testes, ovary, and vitelline gland in $R$. ondatrae, and by the position of the ovary and vitelline gland relative to the testes, the shape of the ovary, the spirally coiled proximal end of the vagina, and the apparent lack of a cirrus stylet in this species (Rider and Macy 1947).

There are four additional species in the genus Retinometra whose rostellar hooks are unknown. Retinometra pauciovata (Fuhrmann, 1906a) has a smaller cirrus sac and smaller testes than $R$. albeolae, as well as a bilobed ovary and a spherical uterus, which contains few eggs, situated in the middle of the proglottid. Retinometra longicirrosa (Fuhrmann, 1906b) has a cirrus sac that extends to the antiporal excretory vessels and a characteristic vagina not seen in $R$. albeolae (Fuhrmann 1906b).

Staphylepis indica Pandey and Tayal, 1981 and Staphylepis meggitti Pandey and Tayal, 1981 were transferred to Retinomet$r a$ by Schmidt (1986). Both species have a rostellum but lack hooks, and have an ovary and vitelline gland situated between the poral and middle testes, and neither has a cirrus stylet (Pandey and Tayal 1981). The arrangement of the ovary and vitelline gland and the lack of a stylet readily separate these two species from $R$. albeolae, and in our opinion also clearly preclude their inclusion in Retinometra. We believe that they were correctly placed in Staphylepis by Pandey and Tayal (1981) and should be returned to it.

Three species among those listed in Hymenolepis s.l. by Yamaguti (1959) and Schmidt (1986) have 8 rostellar hooks that fall within the range of lengths under discussion. Retinometra albeolae can be distinguished from each as follows. Hymenolepis baschkiriensis (Clerc, 1903) (hooks $73 \mu \mathrm{m}$ ) has a shorter cirrus sac that reaches a maximum length of $140 \mu \mathrm{m}$ (Clerc 1903); Hymenolepis guadeloupensis Graber and Euzeby, 1976 (hooks 58-63), has shorter rostellar hooks and a longer cirrus sac $(775-1000 \mu \mathrm{m})$, and the antiporal testis lies beyond the antiporal excretory vessel (Graber and Euzeby 1976). Hymenolepis smythi Singh, 1959 resembles $R$. albeolae in proglottid morphology but has shorter hooks $(55-62 \mu \mathrm{m})$, a larger cirrus sac $(510-780 \mu \mathrm{m})$, which extends to the antiporal excretory vessel and an accessory sac (Singh 1959).

\section{Acknowledgements}

We thank Mr. E. Whitney, Canadian Wildlife Service, for the necessary permits to collect the buffleheads. Peter Ward and Dr. Bruce Batt graciously provided space at the Delta Waterfowl and Wetlands Research Station, where the collections were carried out. Irene Menaggia kindly translated Maksimova's paper from Russian. This work was supported by Natural Sciences and Engineering Research Council of Canada grant A-6979.

Bush, A. O., and Holmes, J. C. 1986. Intestinal helminths of lesser scaup ducks: patterns of association. Can. J. Zool. 64: 132-141.

CLERC, W. 1903. Contribution a l'étude de la faune helminthologique de l'oural. Rev. Suisse Zool. 11: 241-368 and plates 8-11.

CZAPLINSKI, B. 1965. Retinometra guberiana sp.n. (Cestoda, Hymenolepididae), a new cestode species from Cygnus olor (Gm.) Acta Parasitol. Pol. 8: 35-39.

FuhrmanN, O. 1906a. Die Hymenolepis-Arten der Vogel. Zentralbl. Bakteriol. Parasitenkd. Infektionskr. Hyg. Abt. 1 Orig. 41: 440452 .

$1906 b$. Die Hymenolepis-Arten der Vogel. Zentralbl. Bakteriol. Parasitenkd. Infecktionskrankh. Hyg. Abt. 1 Orig. 42: $730-755$.

GrabER, M., and EuZEBY, J. 1976. Hymenolepis guadeloupensis n.sp. Cestode nouveau du canard domestique Anas boschas Linné. Ann. Parasitol. Hum. Comp. 51: 199-205. 
Maksimova, A.P. 1966. New cestode: Retinometra oxyurae sp.nova (Cestoda: Hymenolepididae) from the wild goose of Kazakhstan. (In Russian.) Helminthologia, 7: 291-295.

MAYHEW, R. L. 1925. Studies on the avian species of the cestode family Hymenolepididae. Ill. Biol. Monogr. No. 10.

MegGitT, F. J. 1933. Cestodes obtained from animals dying in the Calcutta Zoological Gardens during 1931. Rec. Indian Mus. (Calcutta), 35: 145-165.

Pandey, K. C., and Tayal, V. 1981. On two new cestodes of the genus Staphylepis Spassky and Oschmarin, 1954. Indian J. Parasitol. 5: 43-46.

PFEIFFER, H. 1960. Hymenosphenacanthus bulbocirrosus spec.nov. (Hymenolepididae), ein neuer Bandwurm des Schwarzhalsschwanes. Z. Parasitenkd. 20: 345-349.
Rider, C. L., and MACY, R. W. 1947. Preliminary survey of the helminth parasites of muskrats in northwestern Oregon, with a description of Hymenolepis ondatrae n.sp. Trans. Am. Microsc. Soc. 66: 176-181.

SCHMIDT, G. D. 1986. Handbook of tapeworm identification. CRC Press, Boca Raton, FL.

SingH, K. P. 1959. Some avian cestodes from India. III. Species belonging to the family Hymenolepididae. Indian J. Helminthol. 11: 43-62.

Yamaguti, S. 1959. Systema helminthum. Vol. 2. The cestodes of vertebrates. Interscience Publishers, New York. 